\title{
THE MYTHICAL CYCLE OF MORTAL LEGACY IN DAN PAGIS' WRITTEN IN PENCIL IN THE SEALED RAILWAY-CAR
}

\author{
Sreekanth Kopuri \\ Assistant Professor, Department of English, \\ SVIET Machilipatnam \\ Email: sreekanthkopuri@gmail.com \\ Mob: 09701036313
}

\begin{abstract}
While literature ceaselessly strived to document various aspects of human life throughout the ages, the archives of its history so far haven't filed the adequate collection on genocides which are the recurrent barriers to the harmonious continuity of human existence. Dan Pagis' poem encompasses a mythical magnitude of the holocaust which symbolically portrays the cyclic iteration of primordial atrocity originating from the evils of jealousy, hatred and exploitation. The deceptive brevity and simplicity of the poem has a spatial possibility of a detailed interpretation of the concepts of fratricidal death, isolation and the existential ordeal of survival as a continuity of the violence and the ancestral horror in the 'boxcar' of our civilization. The abrupt ending of eve's words in the poem denotes a perpetual contortion of the human cycle from the beginning and the continuity of the same. Whether it's for the betterment of the human future which is a kind of purgation or for the worst which is a kind of poetic judgment; the density of the poem with the echo of terror in its tone shows that the human race must pass through the endless phases of destruction and creation the cycle of which continues in various forms of catastrophes and regeneration of the new.
\end{abstract}

Key Words: Holocaust, existential, horror, myth, creation, destruction.

Sooner or later in life everyone discovers that perfect happiness

Is unrealizable, but there are few who stop to consider the antithesis;

that perfect unhappiness is equally unattainable.

-- Primo Levi, Survival in Auschwitz

If the meaning of literature has been established more as an "imitation of life", then the post-war definition of it in the literature of the Holocaust must be more a representation of death and suffering. These themes have been best defined by Emile Dickenson, Dylan Thomas, Pablo Neruda and Sylvia Plath in their timeless classics but the magnitude of suffering from 1933-45 represented in the literature of the holocaust stands as a monumental record of unprecedented human suffering. This is the reason why Theodre Adrono said, "To write poetry after Auschwitz is Barbaric." The endlessly excruciating pain which is portrayed in the poems like Paul Celan's Todesfugue, Mary Elizabeth Fry's Do Not Stand at My Grave and Weep, Miklos Radnoti's Postcards, Yala Korwin's The Little Boy With His Hands Up etc showcase 
ELK

Asia Pacific Journals

a human saga that wasn't before. The Holocaust has a silent echo of something that is a controlled by an unseen force which implies that it is the part of the cycle connected somewhere beyond the human grasp. This mythical background is always a major subject of discussion. Both from the Christian and the Jewish point of view, the Holocaust has been considered as an act of purgation. After all the arguments one concept continues in the Jewish life destruction follows creation. Examples are "the earth was without form and void and darkness was upon the face of the deep." (Genesis 1:2), The flood, the fire in Sodom and Gomorrah, the Plagues and ultimately the Holocaust.

Much Literature of the Holocaust has represented this concept. Dan Pagis' poem, written in pencil in the sealed railway-car aptly justifies this. Pagis is an Israeli poet and a Holocaust survivor who escaped the Ukrainian concentration camp at the age of 14. The poem is very small but the scope is mythically large. Most part of the poem is silent but the deceptive vastness of its theme speaks of much of the holocaust in the style of documentary literature. It is the brilliant and painful imagery and the technique of silence that create the theme of the poem.
ELK Asia Pacific Journals - Special Issue

ISBN: 978-81-930411-1-6

The poem very small is completely off the normal experience that one cannot respond to it without the Biblical or the Jewish History. Mark the dense imagery and the deceptive brevity of the poem which covers the entire sealed fate of humanity:

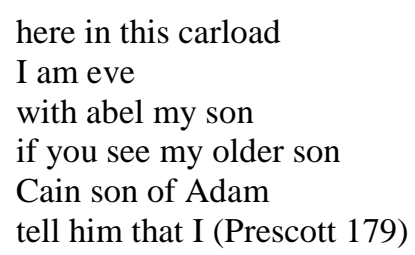

The terrifying silence in the abrupt ending of the poem "tell him that I.." (Pagis 29) has a mythical connectivity to a cycle of 'here' and 'there' which indicate both mortality and immortality, destruction and creation. There is philosophically much than mere juxtaposition of the colliding tones. The end has a strong coherent connection to the beginning and vice versa. The tone of the poem is from some suffocating indoors with cryptic words as if we ourselves are imprisoned as it is an artifact from the Holocaust. The relevancy of the images in the first line, "here in this carload", and that in the last line, "tell him that I.." evoke the recurring act in the Judaic tradition in which the scriptural passages are read again and again; when one finishes reading, one goes back to the beginning to start reading once 
Asia Pacific Journals

again. Here the recurrent style of the interpretive technique supports the theme of beginning or a rebirth. The Hebrew meaning of "eve" is "life" which denotes "I'm alive." This recurrent cycle of survival shows that man has to endure the grief or in spiritual point of view the mortality which is the "wages of sin." Further this theme is symbolically interpreted with the phrase "written in pencil" in which the grey colour denotes hopelessness or death or the tragic fate of the recurrence of human fate due to the "original sin" of which Tatha Wiley says, "the doctrine of original $\sin$ assumed monogenism, the original emergence of two human beings from whom all other descended" (Wiley 118)

The indeterminate and the frightening end of the poem is a clue and a larger message in the Jewish point of view that something terrifying is also about to

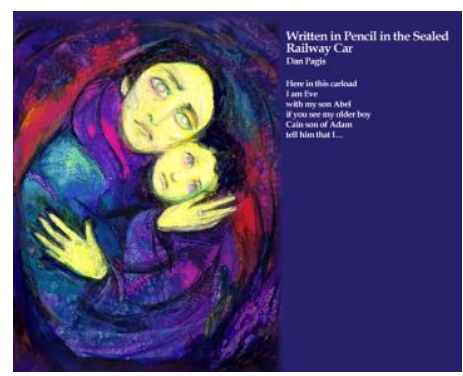

Painting by Lis Elsby. 2015. Yad Vahsem. The Holocaust Martyrs and Heroes Remembrance Authority begin. This desperate iteration and reiteration signifies the process of the ending and another beginning of some destruction in this context the Holocaust. Apart from mere dying words of Eve they also revert to the very first verses of Genesis. Eve's words of panic from the Boxcar are a "collective conscious" of all the writer's fellow victims who are soon to be executed. The loss that is imminent shortly is not only the loss of the 'originator of people but a loss of an important identity. So, this is not just a personal story of the writer but a universal one.

The reference to "Abel my son" means the people of Abel - the multitude of holocaust victims. The presence of Abel with him shows her sympathy and love with him. This is best expressed in the following painting by Lis Elsby at the Yad Vahsem:

Cain the older son implies the son of Adam or the roots of Adam. It also implies the "Cain the son of blood" and "son of soil." In Hebrew phrase this is called Cain Ben Adam. The phrase also in this context refers to the repetition of some primordial activity - the fratricide which is Cain's murder of Abel. According to the poem this atrocity of brother killing brother and the 
ELK

Asia Pacific Journals

end of the universal brotherhood is cyclical which is denoted by the Holocaust. One end after another comes which is already forecast as "kaliyuga" and in the Christian philosophy the "Rapture" mentioned in the chapter of Revelations." The poem also speaks of an imminent fate to the mankind which is symbolized in the caged intimacy in the suffocated confinement of the 'box car.' No one can escape this. By referring to this sealed fate, Pagis 'summons the heritage of all humanity into the railway car. Besides concern he also demands our participation.

The references to the brothers "Abel" and "Cain" suggest that one grown into a human and one grown into a tribe but contained in the same family. The escape from the horror of the imminent mass destruction is illusory. The poem is also a warning from the one of the victims of the Holocaust to every eve, Adam Cain and Abel about the renewal of the ancestral horror in today's metaphoric Holocaust. It is true that one must flee from this horror but one should not be silent because callousness to other man's suffering is a common failure to the society. This can be best explained in the words of Martin Miemoller in his poem "First They Came for Socialists" said:
ELK Asia Pacific Journals - Special Issue

ISBN: 978-81-930411-1-6

Then they came for the Jews, and I did not speak out-

Because I was not a Jew.

Then they came for me-and there was no one left to speak for me. (Darwish 42)

As Cain's hands is stained with the blood of his brother "Abel" so are the hands of the Nazis stained with the bold of Holocaust victims. Hence the poem is a serious warning to humanity that we are the architects of the continuation of this cycle if we are not aware of the human species being fossilized in the museums of the memories of the generations to come.

\section{References:}

[1] King James Version

[2] Prescott, Doborah Lee. Imagery from Genesis in Holocaust Memoirs, North Carolina, 2010.print.

[3] Pagis, Dan. The Selected Poetry of Dan Pagis. California: University of California Press, 1989.print.

[4] Wiley, Tatha. Original Sin: Origins, Developments, Contemporary Meanings. New York: Paulist Press, 2002.print.

[5] Darwis, Mordehay. Israel Must Decide. Indiana: Xlibris Corporation, 2003.print. 